\title{
Rethinking Colonialism and the Origins of the Developmental State in East Asia
}

\author{
WONIK KIM \\ Department of Political Science, Louisiana State University, Baton Rouge, USA
}

\begin{abstract}
Previous studies on economic development in East Asia focus exclusively on the recent period (since the 1960s) and posit that East Asian "miracles" were largely a result of the state's exceptional capacity to implement consistent industrial policy. Yet, they neglect the question of the origins of the developmental state. To confront this neglect, this article makes a macro-historical comparison between Northeast and Southeast Asia, highlighting colonialism, the role of income inequality, and subsequent socio-economic transformations. It is argued that a crucial historical phase for new economic trajectory was the decolonisation period when East Asian countries had an opportunity to break away from negative colonial legacies. This article sheds new light on the ways in which colonialism shapes long-term economic development in East Asia.
\end{abstract}

KEY Words: Economic development, inequality, colonialism, the developmental state, East Asia

In 1820 , the richest country in East Asia was the Philippines, while the poorest area was today's Taiwan. A hundred and fifty years later, c. 1970, the level of economic development in Taiwan was double that in the Philippines. Thirty years later, we now pay witness to Taiwan with a per capita income seven times higher than that of the Philippines. The difference between their rates of growth in per capita income is remarkable as well. For 1970-2000, the average growth rate in Taiwan was 7\%, while that in the Philippines was $1 \%$. Using Lucas' (1988) rule of thumb to obtain the number of years it takes for income to double (divide 70 by the growth rate), we can see that the Philippines' per capita income will double every 70 years; Taiwan's, every 10 years. Taiwan has achieved an economic miracle, while the Philippines is locked in a poverty trap. These two countries' divergent economic performances largely reflect an overall difference between Northeast Asia and Southeast Asia. For a long time, Southeast Asian countries in general were as rich as, or even wealthier than, Northeast Asian counterparts. Yet they fell behind. A clear "reversal of fortune" took place in East Asia in the 1960s and 1970s, and the income gap between these two regions has been getting wider ever since. 
The general purpose of this article is to explain why this happened. The predominant explanation has been provided by the developmental state theory. Although the previous studies in this research paradigm are successful in identifying the positive features of the East Asian state apparatus that contributed to phenomenal economic growth, they have neglected the question of the origins of the developmental state. Taking this issue seriously, I have conducted a macrohistorical comparison between Northeast Asia and Southeast Asia. Based on the theoretical framework of comparative colonialism recently developed in the field of political economy, I argue that the developmental state fundamentally requires relative income equality as the initial socio-economic condition. Some of the Northeast Asian countries (e.g., Japan, Taiwan and Korea) undertook radical land reforms that dramatically equalised income in society. While most Southeast Asian countries inherited "extractive colonial institutions" that perpetuated income inequality, Korea and Taiwan were able to break away from the colonial legacy, which allowed the emergence of the developmental state.

This article is organised as follows. The next section provides a critical review of the developmental state theory. This is followed by a discussion of divergent economic trajectories in Northeast and Southeast Asia from a historical perspective. The next section explores theoretical issues and presents the various findings including results from statistical analysis. The final section provides a brief summary.

\section{The Developmental State Revisited}

It seems to be now generally accepted that the success of the East Asian tigers - with Japan as a pioneer, South Korea, Taiwan, Singapore as models, and China as a tiger still waking up - was largely a result of the crucial role played by the state. The literature on East Asian "miracles" marshals abundant evidence to focus its explanations exclusively on the East Asian state's exceptional capacity to implement industrial policy leading to phenomenal economic growth (e.g. Amsden, 1989; Chibber, 2003; Evans, 1995; Johnson, 1982; Wade, 1990; Woo-Cumings, 1999). The research paradigm in this literature largely centres on the developmental state, providing a hopeful solution to those who have been disillusioned by neo-classical theory's universal policy implications as well as dependency theory's impotent policy prescriptions.

Neo-classical economic models generally posit that the role of the state should be minimal in generating economic development, since any external influence other than market imperatives would distort the allocation mechanism, dampen incentives to invest, lower economic growth, and ultimately lead to a Pareto inefficient outcome where some people are worse off due to the centralised allocation mechanism of state intervention. The crux of policies adhering to the "official" doctrine of the World Bank is fundamentally neo-classical and sends a strong universal message to developing countries: deregulation, privatisation, central bank independence, independent judiciary, and dismantling of the welfare state.

Dependency theory, emerging from Latin American experiences, criticised this kind of universal message, claiming that developing countries' retardation in terms of economic development is due to the mode of "insertion" of national economies into the world economic system (e.g. Carodoso and Falleto, 1979). This suggests that 
underdevelopment is structural in that emulating "right" policies à la Washington Consensus cannot change poverty traps and may even deepen them.

The success of development state theory lies in its explanatory power, which suggests a starkly opposite message to the neo-classical one. Based on particular experiences in selective East Asian countries, this theory shows that the tiger economies achieved miracles by doing exactly what the World Bank had told them not to do: selecting and disciplining industries, connecting bureaucrats to businesses, and "getting relative prices wrong" (Amsden, 1989). The theory has gained notable attention from many scholars and decision makers for the particularity, not universality, on which it is based. Moreover, it is this East Asian particularity, as opposed to Latin American particularity, that has given poor countries a practical solution to escape from their poverty traps. Not only is the theory practical, but it is also attractive, because the tigers' phenomenal growth and rapid transformation from poverty traps to miracles have left a strong impression that there is some sort of a short cut to sustainable high growth, namely a "pathway from periphery" (Haggard, 1990).

What is the engine of East Asian miracles? Although developmental state theorists of different stripes propose various explanations, we can summarise the central formulation of developmental state theory as follows. ${ }^{1}$ First, a particular industrial policy is required to rapidly transform the "easy stage" of import-substituting industrialisation to export-orientated industrialization (EOI). Essential to this type of industrial policy is selecting promising industries and sectors, and then protecting, subsidising, and disciplining them. Secondly, the state needs a strong capacity to implement and sustain "big push" programmes. The state must also have an ability to insulate itself from particular interests in society. State capacity and insulation are two pillars of state autonomy, and usually they are embodied in a bureaucratic nodal agency that can co-ordinate industrial policies (e.g. Japan's Ministry of International and Trade Industry or MITI and Korea's Economic Planning Board or EPB). Finally, the state is not only autonomous but also embedded in society: there is a tight network of informal institutional linkages between economic planners in the state and business sectors in society. This embeddedness helps the state to adopt optimal industrial policies that maximise industrial interests and, as a positive externality, social interests in the form of a high level of economic development. Thus, a set of industrial policies characterised by EOI, state autonomy (capacity and insulation), bureaucratic co-ordination institutions, and embeddedness are the necessary elements for the developmental state to produce economic miracles.

Developmental state theory has been so successful in explaining the remarkable East Asian economic performances that even the World Bank (1993), the centre of neo-liberal doctrine, has come to admit the role of the state and to incorporate some of its elements in its recommendations to other developing countries. In fact, statedirected industrial policy is not just an East Asian phenomenon; it has also a strong affinity with some of the European countries' mercantilism in the early nineteenth century. Chang (2002) shows that state intervention in the economy is not a particular response that happened in specific historical contexts in East Asia, but a universal feature common to all of the successful economies at an early stage of their industrialisation, including England and the USA, currently hailed by liberal market advocates as a paragon of success. If we accept this claim, the developmental state 
theory ceases to be a model of particularity but aims at universality, so that other developing countries can emulate the East Asian model.

The conventional economic critiques of developmental state theory centre on the causal link between the EOI and actual economic outcomes. Rodrik's (1995) detailed study reveals that East Asia's growth can be largely accounted for by its rapid capital accumulation and investment and that the growth had little to do with industrial policy. In fact, he argues that the ELI was the result, not the cause, of economic success. Another set of careful calculations was done by Young (1995) for the four East Asian Newly Industrialised Countries (NICs) (Hong Kong, Taiwan, Korea and Singapore). For these countries, technological innovation and efficiency enhancement measured by total factor productivity were very low during the miracle period, but the rapid accumulation of capital and high level of labour force participation were the main contributors to total growth. In other words, economic success was based purely on perspiration rather than inspiration. These findings led Krugman (1994) to argue that there is nothing mysterious about the Asian miracles, and that economic performance based on the mere increase in inputs (capital and labour), as in the case of East Asia, will inevitably show diminishing returns.

The main problem with these arguments is that they still need to explain why some East Asian countries were able to mobilise a tremendous labour force and successfully launch a big push to industrialise, while other developing countries simply did not conduct such a bold economic plan. What the arguments criticise is the effectiveness of the developmental state's strategy, which may not lead to sustainable growth, but their theory nevertheless takes as a premise that state capacity and insulation are at least necessary for input-driven growth.

Another line of critique targets the nature of embeddedness. There is no theoretical reason to believe that connection between economic bureaucrats and business sectors will entail optimal policies. Indeed, one can think that a natural consequence from this connection is collusion or monopoly, which in turn creates moral hazards for industrialists and investors, ultimately resulting in a deadweight loss for society. This critique has gained some empirical credibility after a series of corruption scandals were revealed in Japan and South Korea during the 1990s and after the Asian financial crisis erupted in 1997. The economy under the developmental state was nothing but "crony capitalism" (Kang, 2002). The critique is valid, for the developmental state theorists are usually silent about the negative externalities of embeddedness to the overall economy, and usually they do not specify the condition under which this close linkage necessarily leads to economic development. Notice that this was a typical liberal rationale for the IMF-style structural adjustment programmes in the countries hit by the financial crisis of 1997. Yet even some critics of money politics in East Asia argue that some sort of rentseeking behaviours or capture of private goods can be necessary for economic development; otherwise there would be no incentive for both ruling elites and industrialists to provide public goods (Kang, 2002). Seen this way, the problem becomes simply a question of degree - how tolerable are bribery and money politics for overall economic development? And, to be sure, money politics has been an issue for more than just the East Asian countries. ${ }^{2}$

All these conventional critiques and debates largely miss one important aspect of development state theory: the question of the origins of the developmental state. 
Most studies on East Asian miracles have focused exclusively on the 1960s-80s, when "big push" industrialisation was launched and worked effectively. They have not succeeded in resolving a problem arising from the endogeneity of the developmental state; they take this type of institution as exogenous, neglecting the fact that the creation of these institutions is linked with socio-economic factors that may be correlated with economic development. In other words, they have not fully explored the origins of the developmental state. As Cumings (1984: 3) points out, "[i]f there has been an economic miracle in East Asia, it has not occurred just since 1960; it would be profoundly ahistorical to think that it did." To confront these difficulties, it is necessary to consider a longer historical experience of East Asia: its colonial legacies, the institutional frameworks inherited or established at independence, and subsequent political socio-economic transformations.

Some detailed case studies have broadened our historical horizon, going back to the colonial period and highlighting the historical continuity of economic development. Eckert (1991) and McNamara (1990) document in detail the historical formation of key Korean enterprises and argue that Korean capitalism and its subsequent economic growth would not have been possible without Japanese colonialism. In this spirit, a group of Korean economic historians at the Nakungdae Institute have recently published a series of impressive empirical studies, in which they argue that the basic industrial infrastructure necessary for the subsequent economic miracle had been established already under Japanese colonial rule (Kim, 2006; Lee, 2004; Park, 2006). Political scientists Kholi (1994, 2004) and Krieckhaus (2006) repeat this Japanese lineage thesis. These scholars provide solid evidence about economic improvement during the Japanese colonial period, but, for their continuation thesis to work, the economic downturn under the "predatory" Lee regime from the end of colonial rule to the 1960s should be explored (Haggard et al., 1997). Their narratives about the effects of Japanese colonialism on post-colonial economic success are not grounded in theory or empirical observation that systematically supports the continuation. ${ }^{3}$ A more serious problem with these studies is their lack of comparative analysis. As we see in the next section, for a long period of time some of the Southeast Asian countries were as rich as, or even wealthier than, Korea and Taiwan. It may be true that the Korean economy grew during the Japanese colonial period, just as Southeast Asian economies grew to an even greater extent during the European colonial period. Yet the countries in Southeast Asia all fell behind Korea and Taiwan in the late twentieth century.

Another argument takes a different perspective to explore the origins of the developmental state. Taking Tilly's (1985) famous assertion seriously - "war makes the state, and the state makes war" - this theory emphasises the external threat due to the unique geopolitical environment in East Asia. Unlike most Southeast Asian countries, Taiwan and Korea have faced a severe security threat from the People's Republic of China and North Korea, respectively. In these conditions, the ruling elites in these countries had a strong incentive to increase the size of the economy for their survival. At the same time, the political regime gained co-operation from the citizens who reaped material benefits from the high level of economic growth (Cumings, 1984; Doner et al., 2005; Woo-Cumings, 1999). Moreover, geopolitics meant that Korea and Taiwan received enormous foreign aid from the USA, which enabled them to initiate their industrial transformation (Stubbs, 1999). Although the 
story is plausible for Korea and Taiwan, the external threat thesis can work in an opposite direction. Callahan's (2003) painstaking work suggests that Burma is poor precisely because of this war factor, which has entailed the remarkable durability of the Burmese military regime and a persistent low-growth pattern. "Making enemies" does not necessarily translate into a dramatic increase in economic development.

What is lacking in the existing studies on the origins of the developmental state is the socio-economic factor that gave rise to the developmental state, which in turn brought economic growth. Several recent political economy studies shed new light on comparative colonialism and economic development, by focusing on this socioeconomic mechanism (Acemoglu et al., 2001, 2002; Engerman and Sokoloff, 2002, 2005). They take a historical perspective and provide a sophisticated theory regarding the impacts of different colonial institutions. Building on their studies, I shall argue in what follows that the initial condition with regard to income distribution in a society was fundamental to the emergence of the developmental state, for the egalitarian distribution of income was common to all successful Northeast Asian economies, as opposed to their Southeast Asian counterparts. This income equality was achieved through radical land reforms undertaken soon after independence. In this sense, the economic successes were not because of the continuing influences from colonialism but because of the radical rupture from the colonial legacy. Before I develop this theory and present evidence, a brief discussion of the historical trends in East Asian development is in order.

\section{Historical Trends}

In this section, we take a look at economic development in East Asia from a long historical perspective. Let us look at the raw data. The historical data on income per capita (GDP per capita) are taken from Maddison (2003). ${ }^{4}$ Figure 1 presents income per capita in Northeast Asia and Southeast Asia from 1820 to 2000. ${ }^{5}$ All previous studies have pointed out that the developmental state can be found in Northeast Asia, with the sole exception of Singapore. From this graph, we can clearly identify the divergent trajectories of economic development between these two regions. Notice that on average, Southeast Asian countries were slightly wealthier than Northeast Asian countries for a very long period of time. Divergence in development paths occurred only after the 1960s solely because of the explosive growth in Northeast Asia. The gap has only become wider since then.

The overall accumulation of wealth in Southeast Asia before the twentieth century has been well documented. Criticising Eurocentrism in economic history, recent scholarship has claimed that the largest trade core in the world for almost five hundred years (1300-1800) centred on the Indian Ocean in which Southeast Asia was included and played an important role (Abu-Lughod, 1989; Chaudhuri, 1990; Frank, 1998; Lieberman, 2003; Marks, 2007). According to Frank (1998: xxv), this overwhelming concentration of wealth and resources was a prime incentive for Europeans to colonise this area later on, in other words, to "buy a ticket on the Asian train." These analysts have asserted that the colonisation of Asia enabled Europe to launch the Industrial Revolution in the nineteenth century.

Yet, this picture raises a question about generalisation. Obviously, not all the countries are the same in terms of economic development. Northeast Asia contains 


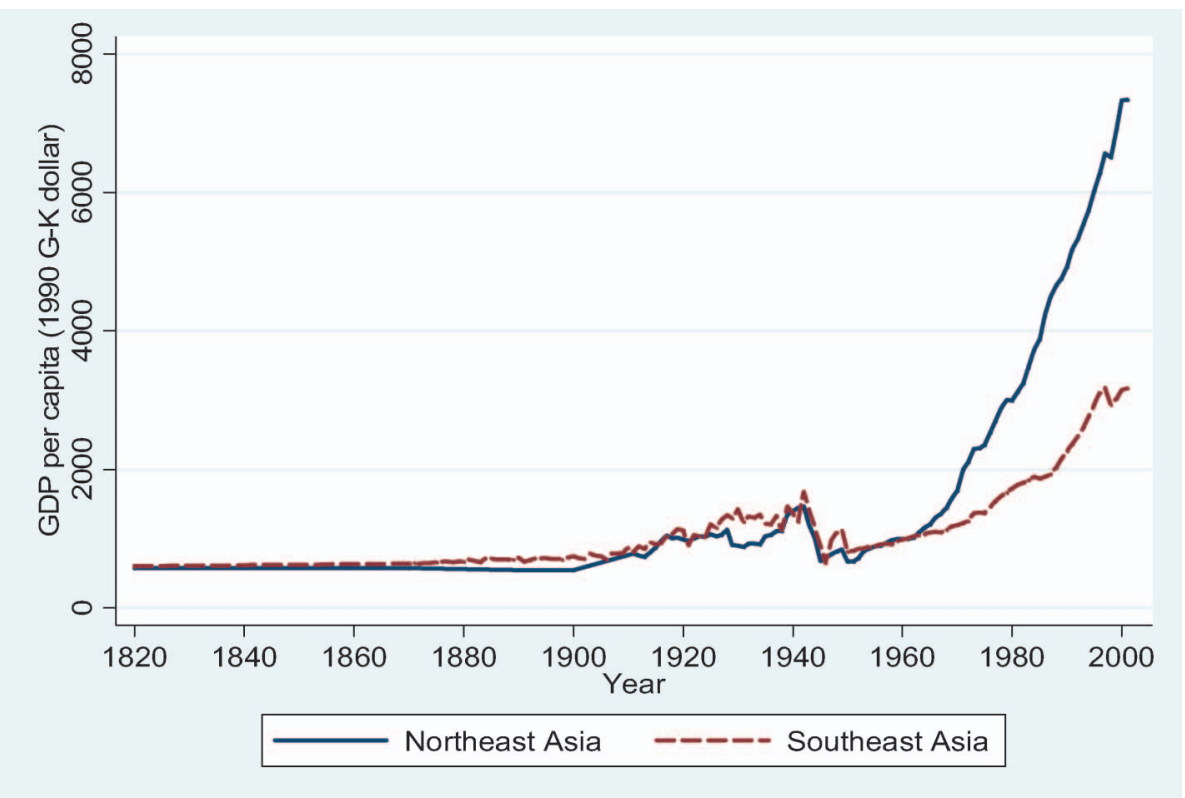

Figure 1. Divergent paths of GDP per capita in East Asia 1820-2000. Source: data are taken from Maddison (2003).

some "disasters" as well as "miracles." Mongolia and North Korea are unsuccessful economies. In Southeast Asia, countries' performances are diverse, with Singapore as a clearly successful outlier; many have also proposed Malaysia and Thailand as second generation tigers. Moreover, Southeast Asian economies did grow over time. Hence, the correct question would be not why Southeast Asia fell behind compared to Northeast Asia, but why most Northeast Asian countries were able to develop exceptionally faster than most Southeast Asian countries in very recent history.

Given this caveat, let us study some countries' actual figures over time. Table 1 breaks down per capita income by selected countries and years. As of 1820, the richest country in East Asia (even in Asia as a whole) was the Philippines, where the per capita income was $\$ 704$. This is not surprising, because the Philippines under Spanish colonial rule played a crucial role as the largest hub in the world silver trade (Pomeranz, 2000: 159-62). Thailand was the third wealthiest country right after Japan, and per capita incomes in Indonesia, Malaysia and Singapore were all similarly high. China ${ }^{6}$ and Korea were slightly behind, and Taiwan was clearly the poorest (\$499). This pattern lasted until the end of the nineteenth century, as we see that the Philippines was still the richest area in 1870. Most countries' economies, save China's, started to grow in the early twentieth century. This early take-off in growth is confirmed by previous case studies, as discussed by the Korean scholars of recent economic history. These findings led them to argue that Japanese colonialism was not completely malevolent, contrary to nationalist Korean scholars' belief. However, because we see an increase in the income level in other countries, we can conclude that economic development was not limited to some peculiarity of Japanese rule; in fact, other countries under European colonial rule grew at even higher rates. 
Table 1. GDP per capita in East Asia by the Selective countries and years

\begin{tabular}{lccrrrr}
\hline Countries & 1820 & 1870 & 1930 & 1950 & 1970 & 2000 \\
\hline Burma & 504 & 504 & 902 & 396 & 646 & 1353 \\
China & 600 & 530 & 567 & 439 & 783 & 3425 \\
Indonesia & 612 & 654 & 1164 & 840 & 1194 & 3203 \\
Japan & 669 & 737 & 1850 & 1921 & 9714 & 21069 \\
Korea & 600 & 604 & 1020 & 770 & 1954 & 14243 \\
Malaysia & 605 & 663 & 1636 & 1559 & 2079 & 7872 \\
Philippines & 704 & 776 & 1476 & 1070 & 1764 & 2385 \\
Singapore & 615 & 682 & 1279 & 2219 & 4439 & 22207 \\
Taiwan & 499 & 550 & 1099 & 924 & 2980 & 16642 \\
Thailand & 646 & 712 & 793 & 817 & 1694 & 6336 \\
Vietnam & 527 & 505 & 724 & 658 & 735 & 1790 \\
\hline
\end{tabular}

Note: GDP per capita is the Geary-Khamis 1990 purchasing power parity dollars.

Source: data are taken from Maddison (2003).

Most countries' per capita incomes, however, either dropped or stagnated right after they became independent. The period from 1945 to the 1950 s was a disastrous era for East Asia as a whole. The decreases in income levels during this period differ from country to country, but they all experienced some kind of economic crisis during the decolonisation period. Burma and Korea were the worst cases. Burma had to face a drop in income of more than $60 \%$, and per capita income in Korea tumbled from $\$ 1020$ to $\$ 770$. The general trend of the income reduction during this period was so evident that we can clearly identify it from the graph in Figure 1. If we accept these figures, the Japanese lineage thesis, which highlights the continuation between the colonial period and the miracle period of the post-1970s, has no face value. The disintegration of colonial administrations left East Asian countries without growth, suggesting economic development under colonialism was unequal development - only beneficial to the colonisers, or in Huh's (2005) apt words, "development without development." But as the scholars for the continuation thesis can argue, it may be that the productive "potential" embedded in physical infrastructures and modern bureaucracy created by colonial regimes remained largely intact during the political economic turmoil of de-colonization, survived the Korean War, and became the main driving force that led to the emergence of the developmental state and its subsequent growth. One cannot evaluate this claim from these simple statistics. We need a different approach, as discussed in the next section.

To summarise the development patterns, it is useful to think in terms of three periods. The long colonial period roughly until the end of World War II was the one in which most Southeast Asian countries were wealthier than their Northeast Asian counterparts. Economic growth was slow for a long time but started to increase during the first half of the twentieth century. We can identify the short period roughly between 1940 and 1960, characterised by the independence era, when colonial institutions suddenly collapsed and nation-state building began. An excessively negative growth rate and a radical decrease in per capita income were the general pattern. Finally, during the last three decades of the twentieth century, 
the great divergence took place, and the gap between Northeast Asia and Southeast Asia was sufficiently large on average. In the next section, I shall argue that what happened during this second period of the short post-colonisation independence phase was crucial for the reversal of fortune that happened in the third period.

\section{Colonial Institutions, Inequality and Long-term Growth}

I have criticised the existing studies of the developmental state for their fundamental theoretical lacuna, namely the issue of origins. The developmental state is not manna from heaven. Stephen Haggard (2004: 56) has recently addressed the same question to the whole body of developmental state literature:

the problem is deeper. The preoccupation with institutions, and the functionalism in much institutionalist thinking, has obscured more fundamental political and social processes that are themselves determinants of institutional form and quality.

This problem with the endogeneity of institutions is serious, because if there is some condition that directly gave rise to the developmental state, we may wrongly attribute the successful economic outcomes solely to the nature of that stateapparatus and its industrial policies. Although some attempts have been made to tackle the question of origins, future studies need a more solid comparative historical perspective and should place more emphasis on socio-economic conditions.

Building on recent theoretical advances in the political economy literature, I argue that income distribution in society is a fundamental cause, not a result, of long-term economic growth. Income distribution is a factor shaped by history and supported by institutions. Acemoglu et al. (2001, 2002), Banerjee and Iyer (2005) and Engerman and Sokoloff $(2002,2005)$ have generalised the idea of historical institutions that determine inequality, which in turn, impedes sustainable economic development. They have extended our usual sample of analysis, going back to the foundational moments of colonisation. They have found that colonial institutions played a crucial role in perpetuating income distribution in society; these initial institutions shaped the evolution of the conditions under which subsequent development would occur. The remarkable finding of Acemoglu et al. (2001, 2002) is that countries that were wealthier in 1500 are the ones that are less developed now, suggesting that the crucial factor for growth in the long term is colonialism.

The theory is briefly as follows. When colonisers arrived in a "new territory," they established two types of colonial institutions, depending on local conditions and the nature of pre-existing institutions. When Europeans colonised the world outside Europe, they found a diversity of local conditions or "endowments" in terms of soils, climates, natural resources, and size and density of the native population. Those areas that had a large labour force, humid weather and abundant natural resources were also characterised by well-developed pre-existing institutions. In those areas, the colonisers had no incentive to do anything but utilise pre-existing institutions and extract the resources, so they established "extractive colonial institutions." 
The important socio-economic outcome from this type of colonial institution was the great degree of income inequality between the coloniser and the colonised. In contrast, those areas that had small labour forces and virtually no pre-existing institutions had little to exploit, so colonisers settled and established "egalitarian institutions" that were good for economic development. Engerman and Sokoloff (2002, 2005) categorise Latin America as a typical example of the former (e.g. institutions that support big plantations known as latifundia) and North America as the latter.

This theoretical framework is very useful for understanding the generic nature of colonial institutions in East Asia. Like their Latin American counterparts, the colonial institutions in East Asia were largely extractive and unequal by nature. As mentioned in the previous section, the new scholarship in Asian economic history points out that Asia as a whole, especially Southeast Asia before the nineteenth century, was the richest area in the world with an abundant labour force and welldeveloped pre-colonial institutions (see Lieberman, 2003). When Europeans colonised Southeast Asia except Thailand, they built purely extractive colonial regimes, and few of them settled. During the whole colonial period in Southeast Asia, the percentage of Europeans in the total population never exceeded $1 \%$, and the highest percentage was $0.77 \%$ in Malaya in 1931. These are extremely small numbers relative to Latin America. In a sense, no Asian colony was a true settler colony, which suggests that the degree of exploitation was huge in this region (Goodwin, 2001: 83-4). It is not difficult to find studies that document the exploitative nature of Asian colonial regimes. For example, Frankema's recent case study of Malaysia shows that the British set up a huge rubber and tin industry only to export these materials, indicating that the Malayan wealth drain was one of the largest. The Gini-coefficient of land inequality right after independence was 0.68 , which is the highest in Asia. ${ }^{7}$ Thus, Malaysia offers "a fine model of a country with highly favorable conditions to tropical cash crop cultivation leading to high levels of land inequality" (Frankema 2006: 11-15).

Contrary to Southeast Asian countries, the Korean Peninsula had a higher number of Japanese who lived in the colony (2-3\% of the total population). Yet this does not mean that the degree of inequality was low in Korea under the Japanese colonial rule. Huh's (2005) empirical study demonstrates that c. 1940, the Japanese, only $0.2 \%$ of total agricultural workers, owned more than $50 \%$ of total arable land and $95 \%$ of total assets in the industrial and mining sectors. Moreover, in the situations where few colonisers settled, they had to implement a kind of indirect rule system, relying on some indigenous intermediaries. This indirect rule always implied a divide and rule strategy. To maximise the efficiency of governance, the colonial ruler co-opted some portion of society, usually landlords, industrialists and intellectuals, into the colonial regime to share economic benefits (Cogneau and Guenard, 2003) Thus, colonial institutions also entailed inequality between the indigenous elites who supported the colonial rule, and the vast majority of the population.

Why is income inequality the main culprit for underdevelopment? Conventional treatments on the impact of inequality on growth typically focus on the impact of inequality on savings or investment rates. Yet a recent political economic formulation in the context of comparative colonialism suggests an institutional 
mechanism through which inequality affects development. Colonial rule involved "bad" institutions that perpetuated income inequality, which, in turn, impedes the provision of public goods and infrastructure, economic opportunities and broad participation in the commercial economy (Engerman and Sokoloff, 2002, 2005). The role of institutions became crucial when "the arrival of a new technology and the opportunity to industrialise" emerged on the horizon. When this new opportunity emerged, the effect of institutions was to block industrialisation.

The elites may want to block investments in new industrial activities because it may be that these outside groups, not the elites themselves, will benefit from these activities ... They may want to block these new activities, fearing political turbulence and the threat to their political power that new technologies will bring (Acemoglu et al., 2002: 1273). ${ }^{8}$

The crucial element in this formulation is the long-lasting effect of colonialism even after independence. The reason is that extractive colonial institutions entailed an extreme degree of inequality, which in turn, benefited the existing ruling elites and ensured them a return to power, rendering institutions difficult to change. As mentioned in the previous section, the historical opportunity that would break these colonial legacies occurred during the 1950s when the colonisers suddenly left the colonies. When the colonisers left, the accumulation of wealth built under colonial institutions was also completely gone. But the institutional structure and social organisation remained intact. The critical question was whether or not the indigenous elites after independence inherited these inegalitarian colonial regimes. Goodwin (2001: 72-105) persuasively explains the political dynamics right after the dissolution of colonial rule, showing that all the Southeast Asian countries - with the sole exception of Vietnam, which made a social revolution - more or less took over the existing colonial institutional structure and established "neo-colonial rule." As a result, profound inequality was inherited as well, and the colonial legacy continued after independence. This observation is consistent with the theory I have advanced. The neo-colonial elites needed inegalitarian institutions to defend their privileges. These elites were unwilling to change institutions, and without the institutional change the new development path could not be realised. Hence, colonial institutions reproduced themselves in the post-colonial epoch.

In stark contrast, Korea and Taiwan experienced a completely different mode of de-colonisation. During the 1950s, they implemented perhaps the most comprehensive land reforms that dramatically equalised income and resources. The details of these remarkable agrarian reforms in Korea, Taiwan and Japan, and their effects on development and income distribution have been well documented and extensively researched (e.g. Borras, 2006; Dorner and Thiesenhusen, 1990; Griffin et al., 2002; Kay, 2002). Here, it is sufficient to point out some facts. After land reforms were introduced from 1949 to 1953 in Taiwan under the Guomindang government, 48\% of agricultural households received land (Griffin et al., 2002: 304-5). Total production in agriculture grew 5\% from 1952 to 1964. In Korea, land reform was first introduced by the US military government in 1945, and further reforms were implemented in 1949 and 1950 under the Korean government. After a series of 
reforms, $65 \%$ of land was redistributed, and $77 \%$ of the farmers came to own land (Borras, 2006: 88). The land reforms in Japan were broadly similar to those in Taiwan and Korea. As a result, income and land inequality in these countries prior to the developmental state $c .1960$ were the lowest among developing countries. Gini-coefficients for land distribution as of 1960 are 0.39 for Japan, 0.47 for Taiwan, and 0.20 for Korea (Griffin et al., 2002: 302). The sweeping land reforms in these countries cut them off completely from the colonial legacy and created the socioeconomic condition of income equality that was favourable for economic development. Rodrik (1995) concludes that almost 90\% of Korea and Taiwan's growth experience since 1960 can be "explained" by this condition of income distribution. Kholi (1994, 2004), who argues for the Japanese lineage thesis, maintains that the Korean and Taiwanese developmental states were very much Japanese-style. But that concerns only the style, neither more nor less.

To schematically summarise the causal argument, one can identify three historical paths of development from the colonisation era, as succinctly depicted in Figure 2. The first path is that the colonisers settled and established egalitarian colonial institutions in the areas where there were scarce resources for development and relatively poor pre-existing institutions. These institutions were "good" for subsequent growth, because they were based on income equality (North America). Secondly, in the areas where there were abundant resources and well-developed preexisting institutions, the colonisers did not settle and created extractive institutions. These institutions were "bad" for growth, because they were based on income inequality. When the moment of independence arrived, the new indigenous elites established neo-colonial institutions and inherited inequality from colonial rule (Latin America and Southeast Asia). These two paths suggest that there is strong path dependency for growth in the long term. But I have presented another path found in rare cases in Northeast Asia. In this path, what matters for subsequent growth is path independency. ${ }^{9}$ The causal story in this trajectory is similar to the one found in Southeast Asia, but there was the rupture or clear break away from

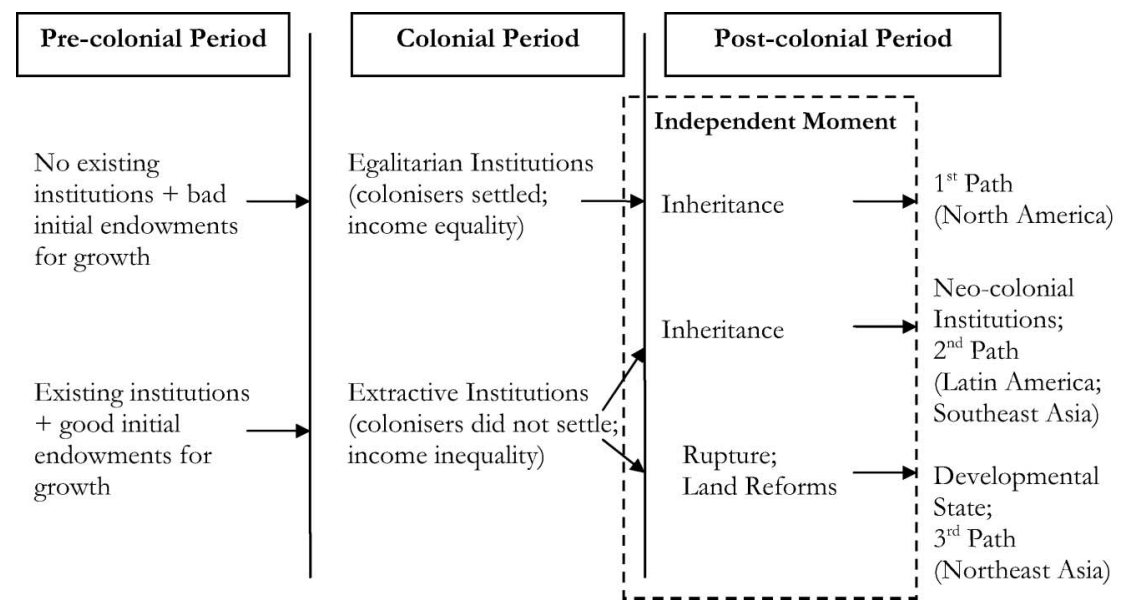

Figure 2. Three histrical paths: a long-term perspective. 
extractive colonial institutions, during the decolonisation period. Radical land reform was the most significant event for this bifurcation. ${ }^{10}$

Land reforms in Northeast Asia were seen as an exogenous shock of historical accident. In this regard, I argue for historical contingency, and the idea of conjuncture works in my story. As Marks (2007: 12) formulates, a conjuncture happens "when several otherwise independent developments come together in ways that interact with one another, creating a unique historical moment." In my story, the disintegration of colonial rule and land reforms - two independent factors - came together and led to a new equilibrium characterised by income equality. This means that once income equality is in place, it must result in a systematically positive effect on development through the developmental state.

One may claim that the inference I have made can be the usual logical fallacy of post hoc ergo propter hoc: because land reforms that equalised income happened to occur prior to the emergence of the developmental state, land reforms caused the emergence of the developmental state. Statistical analysis is one of the proper approaches to establish systematic evidence against this fallacy. Specifically, the purpose of statistical analysis is: (1) to show macro-systematic patterns between income distribution and development, controlling for other factors; and (2) to see if income distribution gave rise to the developmental state. The data are time-seriescross-sectional (the unit is country-year), and the sample of analysis contains fourteen Asian countries from 1870 to 1979 (see note 5 for the countries). The timeseries ends in 1979, due to the availability of data on income distribution. Given the paucity of data for the early years, there are missing observations.

First, let us analyse the impact of income distribution on development. The dependent variable is per capita income taken from Maddison (2003). Historical data on income distribution comparable across countries are difficult to come by. Vanhanen's (1997) dataset on the percentage of family farms is widely known as the most comprehensive in terms of coverage of years and countries. The percentage of family farms (Family Farms) captures the degree of concentration and therefore inequality in the ownership of land. ${ }^{11}$ A higher value of this variable indicates a higher equality of land ownership. The variable Stateness captures the degree of state-building, taken from Bockstette et al. (2002). The highest value of this variable indicates a completely independent and centralised state. To account for the impacts of colonial legacy in terms of type of colonisers, I include five coloniser dummy variables: UK, France, Netherland, Spain, ${ }^{12}$ and Japan. The panel-corrected standard errors (PCSEs) are used to correct for various economic problems with the panel data. I also include the period dummies to correct for duration dependency underlying the data. The first column in Table 2 reports the estimates from the PCSEs model.

All the coefficients are statistically significant at the conventional $5 \%$ level, except the one for Spain. Notice the directions of covariates. The positive signs of the covariates of Stateness and Family Farms clearly indicate that the more independent the state is, and the more equalised the income is, the higher the per capita income is likely to be. The colonial legacy is positive for development in countries that experienced British and Japanese rule (not reported), but once Stateness and Family Farms are included, the positive effect of the colonial legacy disappears, as we see the negative signs of the coefficients of those coloniser dummies. This means that the 
Table 2. Effects of income distribution on per capita income from 1870 to 1979

\begin{tabular}{lcc}
\hline Independent Variables & PCSE Model & Treatment-effects Model \\
\hline Stateness & $29.14(14.59)$ & $30.83(10.22)$ \\
Family Farms & $35.06(5.09)$ & $-516.91(134.83)$ \\
UK & $-1215.48(227.59)$ & $-962.83(179.80)$ \\
France & $-1601.79(211.34)$ & $-529.90(224.56)$ \\
Netherland & $-1390.29(251.99)$ & $-133.42(213.03)$ \\
Spain & $-344.79(236.09)$ & $5375.36(275.22)$ \\
Japan & $-1049.78(219.81)$ & First Stage: DV $=$ Development State \\
Developmental State & & $0.13(0.04)$ \\
& & $1.36(0.89)$ \\
Family Farms & & $0.21(0.14)$ \\
Japan & & 586 \\
Observation & 586 &
\end{tabular}

Note: Standard errors are in parentheses; coefficients of period dummies and constants are omitted due to the limited space.

impacts of income distribution and independence are so great that they overwhelm the effects of colonial legacy. This finding confirms my argument that the relationship between the Japanese lineage and subsequent development is spurious.

Is income equality a crucial socio-economic factor that gave rise to the developmental state, which in turn produced economic development? The causality runs through two links: income equality $\rightarrow$ developmental state $\rightarrow$ economic development. To account for this causal pattern, we need the treatment-effects model that endogenises the developmental state. It is a two-stage model in which the first step is to model the binary decision of the developmental state, and the second step is to analyse economic development affected by the developmental state. ${ }^{13}$ The difficulty is to measure the developmental state. Since the developmental state is a multi-complex state-industry apparatus, it is almost impossible to quantify. Given this caveat, I use a crude measure of the dummy variable (Developmental State), coded 1 for the presence of the developmental state, and 0 otherwise. The decision of the timings of the emergence of the developmental state is based on Doner et al. (2005).

The second column in Table 2 shows the results from the treatment-effects model. The coefficient of Family Farms is positive and highly significant at the 1\% level, clearly indicating that income equality is positively associated with the likelihood of having the developmental state. Yet the Japanese colonial lineage does not affect the emergence of the development state, as the coefficient of Japan is not statistically significant. And the highly significant estimate of Developmental State indicates a quantitatively large, positive impact on per capita income. The change into the developmental state results in an increase in per capita income by $\$ 5375$. In sum, these findings empirically validate our discussions about the importance of income distribution on the origin of the developmental state. The successful developmental state emerged only if certain socio-economic conditions were present, and this condition appears to be income equality. 


\section{Conclusion}

The existing studies on the developmental state have focused exclusively on the period since the 1960s and posited that certain politico-economic institutions largely explain divergent developmental paths between Northeast and Southeast Asia. Yet they have not succeeded in resolving a problem arising from the endogeneity of institutions; they take institutions as exogenous, neglecting the fact that the creation of such institutions initially was linked with socio-economic factors, such as income inequality, that may be correlated with economic development. In other words, they have not fully explored the historical origins of the developmental state. To confront these difficulties, I have conducted a macro-historical comparison of Northeast and Southeast Asia, focusing on inegalitarian colonial institutions, the role of income inequality, and subsequent political socio-economic transformations. I have found that the crucial historical phase was the moment of independence when East Asian countries had an opportunity to break away from the colonial legacy. The successful developmental states in Korea and Taiwan were fundamentally based on relative income equality, and the equalisation of income was radically achieved in the form of land reforms. In contrast, most Southeast Asian countries inherited colonial rule and, as a consequence, income inequality was perpetuated.

\section{Notes}

1 The literature on the developmental state is enormous and, in a sense, the developmental state has been "over-studied," in Kholi's words (2004: 84). Some of the representative works would include a classical work by Johnson (1982) who coined the term "the developmental state" in the East Asian context, and would also include Amsden (1989), Chibber (2003), Evans (1995), Haggard (1990), Wade (1990), Weiss (1998), and Woo-Cumings (1999).

2 Przeworski and Curvale (2005: 2) reminds us of the elusiveness of this critique: "the restrictions on sugar imports, or the Halliburton Iraq contracts, or the 14 million dollar subsidy to the oil industry" have all occurred in the USA, but none of these was supposed to be possible in the USA, whose economic system is not based on cronyism.

3 As evidence for the continuation thesis, Kholi $(1994,2004)$ even mysteriously cites the fact that the founder of the Korean developmental state, Park Chung-Hee, was educated in the Japanese Military Academy during the colonial period. For more nuanced discussions about the Japanese style for the Korean development, see Vogel (1991: 52-4).

4 Maddison's GDP per capita data are based on Geary-Khamis 1990 purchasing power parity dollars, so that per capita incomes across countries and times are comparable. Maddison's figures are not universally accepted by economic historians, but his dataset is the most comprehensive income series available.

5 Northeast Asia includes China, Japan, Korea (South Korea after 1948), Taiwan and Mongolia; Southeast Asian countries in this sample are Burma, Cambodia, Indonesia, Laos, Malaysia, the Philippines, Singapore, Thailand and Vietnam. Obviously, some of the countries did not exist or were colonies in the past, so here a country refers to a territorial boundary that we know now.

${ }^{6}$ Notice that what we observe here is GDP per capita. As Pomeranz (2000: 31-68) shows, the Yangtze area in China, roughly equivalent to the size of England, was the most technologically advanced, and by far the richest area in the world until the nineteenth century.

7 Gini-coefficient is a widely used measure of income inequality. A higher value of this index means a higher degree of inequality, so 1 indicates perfect inequality and 0 means perfect equality.

8 Acemoglu and Robinson (2006: 116) generalise this incentive as "political replacement effect," since "institutional and technological change will increase the likelihood that the elites will lose power, creating the political replacement effect." 
9 For the excellent discussion about path independency, see Przeworski and Curvale (2005).

10 The Philippines also introduced land reform much later in 1979, and more serious reforms were made very recently only after democratisation. A crucial difference between the Northeast Asian cases and the Philippines is the timing. Northeast Asian countries' land reforms took place before the industrialisation that provided the socio-economic conditions favourable for industrial policy. For the importance of this sequencing factor, see Kay (2002).

11 An extensive literature has related the unequal distribution of land to an unbalanced distribution of income. As Boix (2003) reports, Gini-coefficients and Vanhanen's index of family farms are highly correlated.

12 The Philippines was also colonised by the USA as well as Spain, so this dummy variable can be interpreted as the joint colonial legacy of Spain and the USA.

13 Specifically, the first stage model can be written as:

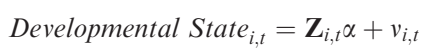

where $\mathbf{Z}$ is a vector of observed factors including Family Farms and $v_{i, t}$ is the error term for country $i$ and year $t$. This first stage model generates an instrument to be used in the second stage model of performance that can be written as:

$$
\text { Income }_{i, t}=\mathbf{X}_{i, t} \beta+\delta I_{i, t}+\varepsilon_{i, t}
$$

where $\mathbf{X}_{i, t}$ is a vector of observed control variables, $\varepsilon_{i, t}$ is the error term, and $I_{i, t}$ is the instrument from the first stage: the propensity score, Developmental State. By connecting these two equations, one can measure $\delta$ the value of the democratic transition controlling for other variables and correcting for the endogeneity. The model jointly estimates the two equations, using full maximum likelihood. Importantly, the random error $v$ is potentially correlated with the error $\varepsilon$ in the performance equation. The model assumes that the errors $v$ and $\varepsilon$ have a bivariate normal distribution with mean 0 and correlation $\rho$. The selectivity correlation $\rho$ is a crucial parameter, indicating whether or not it is necessary to endogenise Developmental State.

\section{References}

Abu-Lughod, J. (1989) Before European Hegemony: The World System A.D. 1250-1350, Oxford: Oxford University Press.

Acemoglu, D., S. Johnson and J. Robinson (2001) "The Colonial Origins of Comparative Development: An Empirical Investigation," American Economic Review, 91, 5, pp. 1369-401.

Acemoglu, D., S. Johnson and J. Robinson (2002) "Reversal of Fortune: Geography and Institutions in the Making of the Modern World Income Distribution," Quarterly Journal of Economics, 117, 4, pp. 1231-94.

Acemoglu, D. and J. Robinson (2006) "Economic Backwardness in Political Perspective," American Political Science Review, 100, 1, pp. 115-32.

Amsden, A. (1989) Asia's Next Giant: South Korea and Late Industrialization, Oxford: Oxford University Press.

Banerjee, P. and L. Iyer (2005) "History, Institutions, and Economic Performance: The Legacy of Colonial Land Tenure Systems in India," American Economic Review, 95, 4, pp. 1190-213.

Bockstette, V., A. Chanda and L. Putterman (2002) "States and Markets: The Advantage of an Early Start," Journal of Economic Growth, 7, pp. 347-69.

Boix, C. (2003) Democracy and Redistribution, Cambridge: Cambridge University Press.

Borras, S. (2006) "The Philippine Land Reform in Comparative Perspective: Some Conceptual and Methodological Implications," Journal of Agrarian Change, 6, 1, pp. 69-101.

Callahan, M. (2003) Making Enemies: War and State Building in Burma, Ithaca: Cornell University Press.

Cardoso, F. and E. Faletto (1979) Dependency and Development in Latin America, Berkeley: University of California Press.

Chang, H. (2002) Kicking Away the Ladder: Development Strategy in Historical Perspective, London: Anthem Press. 
Chaudhuri, K. (1990) Asia before Europe: Economy and Civilization of the Indian Ocean from the Rise of Islam to 1750, Cambridge: Cambridge University Press.

Chibber, V. (2003) Locked in Place: State-Building and Late Industrialization in India, Princeton: Princeton University Press.

Cogneau, D. and C. Guenard (2003) "Colonization, Institutions, and Inequality: A Note on Some Suggestive Evidence," Ms, Unite de Recherche CIPRE.

Cumings, B. (1984) "The Origins and Development of the Northeast Asian Political Economy," International Organization, 38, pp. 1-40.

Doner, R., B. Ritchie and D. Slater (2005) "Systemic Vulnerability and the Origins of Developmental State," International Organization, 59, 2, pp. 473-94.

Dorner, P. and W. Thiesenhusen (1990) "Selected Land Reforms in East and Southeast Asia: Their Origins and Impacts," Asia-Pacific Economic Literature, 4, 1, pp. 65-95.

Eckert, C. (1991) Offspring of Empire: The Koch'ang Kims and the Colonial Origins of Korean Capitalism 1876-1945, Seattle: University of Washington Press.

Engerman, S. and K. Sokoloff (2002) "Factor Endowments, Inequality, and Paths of Development among New World Economies," Economia, 3, pp. 41-109.

Engerman, S. and K. Sokoloff (2005) "Colonialism, Inequality, and Long-run Paths of Development," NBER Working Paper 1157.

Evans, P. (1995) Embedded Autonomy: State and Industrial Transformation, Princeton: Princeton University Press.

Frank, A. (1998) ReOrient: Global Economy in the Asian Age, Berkeley: University of California Press.

Frankema, E. (2006) "The Colonial Roots of Latin American Land Inequality in a Global Comparative Perspective," Ms, Groningen Growth and Developmental Center, University of Groningen.

Goodwin, J. (2001) No Other Way Out: States and Revolutionary Movements, 1945-91, Cambridge: Cambridge University Press.

Griffin, K., A. Khan and A. Ickowitz (2002) "Poverty and the Distribution of Land," Journal of Agrarian Change, 2, 3, pp. 279-330.

Haggard, S. (1990) Pathways from the Periphery: The Politics of Growth in the Newly Industrializing Countries, Ithaca: Cornell University Press.

Haggard, S. (2004) "Institutions and Growth in East Asia," Studies in Comparative International Development, 38, 4, pp. 53-81.

Haggard, S., D. Kang and C. Moon (1997) "Japanese Colonialism and Korean Development: A Critique," World Development, 25, 6, pp. 867-81.

Huh, S. (2005). Development without Development [in Korean], Seoul: Eunhaengnamu.

Johnson, C. (1982) MITI and the Japanese Miracle: The Growth of Industrial Policy, 1925-75, Stanford: Stanford University Press.

Kang, D. (2002) Crony Capitalism: Corruption and Development in South Korea and the Philippines, Cambridge: Cambridge University Press.

Kay, C. (2002) "Why East Asia Overlook Latin America: Agrarian Reform, Industrialisation, and Development," Third World Quarterly, 23, 6, pp. 1073-102.

Kholi, A. (1994) "Where Do High Growth Political Economies Come From? The Japanese Lineage of Korea's Developmental State," World Development, 22, 9, pp. 1269-93.

Kholi, A. (2004) State-Directed Development: Political Power and Industrialization in the Global Periphery, Cambridge: Cambridge University Press.

Kim, N. (2006) Economic Growth in Korea 1910-45 [in Korean], Seoul: Seoul National University Press.

Krieckhaus, J. (2006) Dictating Development: How Europe Shaped the Global Periphery, Pittsburgh: University of Pittsburgh.

Krugman, P. (1994) “The Myth of Asia’s Miracle," Foreign Affairs, 73, pp. 62-78.

Lee, Y. (2004) Late Chosun Dynasty from Quantitative Economic History [in Korean], Seoul: Seoul National University Press.

Lieberman, V. (2003) Strange Parallels: Southeast Asia in Global Context, c. 800-1830, Cambridge: Cambridge University Press.

Lucas, R. (1988) "On the Mechanics of Economic Development," Journal of Monetary Economics, 22, pp. 3-42.

Maddison, A. (2003) The World Economy: Historical Statistics, Paris: OECD. 
Marks, R. (2007) The Origins of the Modern World: A Global and Ecological Narrative from the Fifteenth to the Twentieth-first Century, Lanham: Rowman \& Littlefiled Publisher.

McNamara, D. (1990) The Colonial Origins of Korean Enterprise 1910-45, New York: Cambridge University Press.

Park, J. (2006) Rethinking the Liberation Period [in Korean], Seoul: Chaeksesang.

Pomeranz, K. (2000) The Great Divergence: China, Europe, and the Making of the Modern World Economy, Princeton: Princeton University Press.

Przeworski, A. (2007) "Is the Science of Comparative Politics Possible?" in C. Boix and S. Stokes (eds), Oxford Handbook of Comparative Politics, Oxford: Oxford University Press, pp. 147-71.

Przeworski, A. and C. Curvale (2005) "Does Politics Explain the Economic Gap between the United States and Latin America?" Ms, Department of Politics, New York University.

Rodrik, D. (1995) “Getting Intervention Right: How South Korea and Taiwan Grew Rich,” Economic Policy, 10, 20, pp. 53-107.

Stubbs, R. (1999) "War and Economic Development: Export-Oriented Industrialization in East and Southeast Asia," Comparative Politics, 31, 3, pp. 337-55.

Tilly, C. (1985) "War Making and State Making as Organized Crime," in P. Evans, D. Rueschemyer and T. Skocpol (eds), Bringing the State Back In, Cambridge: Cambridge University Press, pp. 169-86.

Vanhanen, T. (1997) Prospects of Democracy, London: Routledge.

Vogel, E. (1991) The Four Little Dragons, Cambridge: Harvard University Press.

Wade, R. (1990) Governing the Market: Economic Theory and the Role of Government in East Asian Industrialization, Princeton: Princeton University Press.

Weiss, L. (1998) The Myth of the Powerless State, Ithaca: Cornell University Press.

Woo-Cumings, M. (1999) The Developmental State, Ithaca: Cornell University Press.

World Bank (1993) The East Asian Miracle: Economic Growth and Public Policy, Oxford: Oxford University Press.

Young, A. (1995) "The Tyranny of Numbers: Confronting the Statistical Realities of the East Asian Growth Experience," Quarterly Journal of Economics, 110, 3, pp. 641-80. 
Copyright of Journal of Contemporary Asia is the property of Routledge and its content may not be copied or emailed to multiple sites or posted to a listserv without the copyright holder's express written permission. However, users may print, download, or email articles for individual use. 